\title{
Reaction against liver cells by human antiactin antibodies purified by affinity chromatography
}

\author{
KIRSTEN RIISOM, H DIEDERICHSEN, INGER ANDERSEN \\ From the Blood Bank and Department of Clinical Chemistry, Odense University Hospital, Odense, Denmark
}

SUMMARY Human antiactin antibodies were isolated from human smooth muscle antibodies by affinity chromatography using actin extracted from rabbit striated muscle and coupled to activated $\mathrm{CH}$-Sepharose 4B. The eluate contained IgG and IgM smooth muscle antibodies reacting against muscularis mucosae of the stomach and blood vessels. Further the eluate contained IgM antibodies acting against the surface of isolated hepatocytes and the periphery of hepatocytes of sections of liver cells. These results indicate that antiactin antibodies possibly react with the hepatocyte membrane as has been described with regard to other antibodies.

Various tissue antibodies have been found in acute and chronic hepatitis. Of these the bile canalicular antibody ${ }^{1}$ and the liver membrane antibody ${ }^{2}$ react with hepatocytes. It has been suggested that smooth muscle antibodies (SMA), commonly found in hepatitis, ${ }^{3}$ also bind to liver, as many sera from patients with hepatitis and SMA give a so-called polygonal staining - that is, at the periphery of liver cells, with sections of liver. ${ }^{4}$ Smooth-muscle antibodies from patients with chronic hepatitis, ${ }^{56}$ and acute hepatitis ${ }^{78}$ have been found to contain antibodies against actin (AAA). Antibodies against actin produced by immunisation of rabbits have been described as binding to sections of frozen liver in a polygonal manner. ${ }^{9}$ Polygonal staining of liver sections by animal AAA and human SMA might be caused by reaction against smooth muscle antigens in the hepatocyte membrane. A model for testing for antibodies to the liver cell membrane has been reported by Hopf et al who used hepatocytes isolated by a non-enzymatic method. ${ }^{11}$ The possibility of a reaction by AAA against the liver cell membrane does not seem to have been verified on isolated hepatocytes. If human AAA reacted with the liver cell membrane, it might indicate a possible pathogenetic role in chronic hepatitis. We studied purified AAA of human origin for reactivity against isolated hepatocytes and sections of fresh frozen liver. Specific AAA was produced by affinity chromatography with actin. Other antibodies against liver tissue in the human serum would thus be eliminated.

Accepted for publication 2 December 1981

\section{Material and methods}

PREPARATION OF ACTIN

Actin was prepared by gel filtration of acetone-dried powder of striated muscle as described earlier. ${ }^{8}$ The purity of the actin was tested by SDS polyacrylamide gel electrophoresis (PAGE) (Fig. 1).

AFFINITY CHROMATOGRAPHY

Actin (30 mg) was coupled to $1 \mathrm{~g}$ activated $\mathrm{CH}$ -

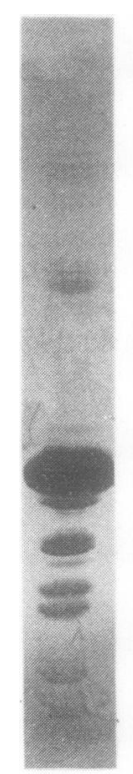

Fig. 1 (a) SDS PAGE of extract of acetone-dried muscle (b) pure actin after gel filtration. 
Sepharose 4B (Pharmacia, Uppsala, Sweden) for one hour at room temperature. The coupling procedure recommended by the manufacturer was followed. Actin-Sepharose gel $(3 \mathrm{ml})$ was poured into a column K9/15 (Pharmacia, Uppsala, Sweden). The column was washed with phosphate-buffered saline pH 7.2 (PBS) containing $0.02 \% \mathrm{Na}$-azide and stored at $4^{\circ} \mathrm{C}$. Serum $(3.3 \mathrm{ml})$ was applied to the column. After incubation at room temperature for half an hour, the column was washed with $40 \mathrm{ml}$ PBS. The last one millilitre fraction of PBS was collected and investigated for negative immunofluorescence reaction against sections of liver and stomach to ensure that the washing had been effective. Antibodies bound to the actin-Sepharose column were eluted with $2.4 \mathrm{ml}$ glycin- $\mathrm{HCl}$ solution, $0.2 M, \mathrm{pH}$ 2.8 in $0.15 \mathrm{M} \mathrm{NaCl}$. Fractions of $0.3 \mathrm{ml}$ were collected. The $\mathrm{pH}$ of the eluted fractions was adjusted to $\mathrm{pH} 7$ by the addition of $\mathrm{NaOH}$.

Immunofluorescence studies were performed on $4 \mu \mathrm{m}$ thick cryostat sections of fresh frozen bovine liver and stomach. ${ }^{10}$ Fluorescein-isothiocyanate (FITC) conjugated anti-human IgG and IgM from the rabbit (Behringwerke, Marburg, Germany) were used. The working dilutions were 1/64. The FITC conjugates were absorbed with lyophilised liver powder. The reactions were read using transmitted light in a Zeiss fluorescence microscope with a HBO $200 \mathrm{~W}$ mercury lamp, an exciter filter BG $12 / 3$ and a Zeiss barrier filter 50 .

Immunofluorescence investigations for antibodies against hepatocytes were performed according to the method of Hopf, et al ${ }^{11}$ with rabbit hepatocytes. Investigations for antibodies in serum were performed with $200 \mu$ l of serum diluted $1 / 2$. Investigations for antibodies in eluate were perfomed with $400 \mu$ l eluate and $0 \cdot 1 \mathrm{ml}$ hepatocyte suspension. The readings were carried out in a Leitz fluorescence microscope with incident light from a HBO $200 \mathrm{~W}$ mercury lamp and an $\mathrm{I} 2$ filter block.

$\mathrm{F}(\mathrm{ab})_{2}$ fragments from sera were prepared as described by Poulsen and $\mathrm{Hjort}^{12}$ by pepsin diges- tion. The pepsin hydrolysate was dialysed. The dialysate was tested for the effectiveness of the pepsin digestion by gel precipitation using anti-Fd (Behringwerke, Germany), anti-Fc (Behringwerke, Germany) and anti-CH2 (kindly provided by $\mathrm{Dr}$ Tage Hjort, Århus). The hydrolysate reacted with anti-Fd, but not with anti-CH2, and gave a spur as compared to normal serum with anti-Fc.

Selected sera sent for investigation for smooth muscle antibody (SMA) were used. The titre for SMA was $1 / 80$ or more except $U 5192$ that had an IgM SMA titre of $1 / 40$. Three sera were from patients with chronic hepatitis (U 5192, Y 1785 and $R$ 6100), one from a patient with acute hepatitis ( $R$ 6103). As negative controls a serum without SMA (X 1785) and pooled serum without SMA were used. None of these sera was from patients with liver disease. The sera were stored at $-30^{\circ} \mathrm{C}$ until used. They were inactivated at $56^{\circ} \mathrm{C}$ for $30 \mathrm{~min}$.

\section{Results}

The sera were first studied with regard to IgG and IgM antibodies to smooth muscle and liver. Then an affinity chromatography was performed on each serum. The chromatographic eluates were investigated by immunofluorescence on sections of liver and stomach and on isolated hepatocytes. Three sera had IgM SMA and gave IgM peripheral hepatocyte staining in sections of liver cells (Table 1). The actin affinity chromatographic eluates of these three sera gave immunofluorescence staining with smooth muscle (Fig. 2) and sections of liver (Fig. 3) identical to the original sera. These three sera reacted with isolated hepatocytes before and after affinity chromatography. Positively stained hepatocytes are shown in Fig. 4. The results of the investigation of IgG antibodies are shown in Table 2. Three sera had IgG SMA antibodies. One of the sera reacted with isolated hepatocytes. After affinity chromatography with actin, these three sera reacted with smooth muscle. None reacted with liver.

Table 1 Results of investigations for IgM antibodies to smooth muscle cells and liver

\begin{tabular}{|c|c|c|c|c|c|c|c|c|}
\hline \multirow[t]{3}{*}{ Serum No } & \multicolumn{4}{|c|}{ "Whole" serum } & \multicolumn{4}{|c|}{ Chromatographied serum } \\
\hline & \multirow[t]{2}{*}{$A N A$} & \multirow[t]{2}{*}{$\begin{array}{l}\text { Staining of } \\
\text { smooth muscle }\end{array}$} & \multicolumn{2}{|c|}{$\begin{array}{l}\text { Peripheral staining of } \\
\text { hepatocytes }\end{array}$} & \multirow[t]{2}{*}{$A N A$} & \multirow[t]{2}{*}{$\begin{array}{l}\text { Staining of } \\
\text { smooth muscle }\end{array}$} & \multicolumn{2}{|c|}{$\begin{array}{l}\text { Peripheral staining of } \\
\text { hepatocytes }\end{array}$} \\
\hline & & & $\begin{array}{l}\text { Sections of } \\
\text { liver }\end{array}$ & $\begin{array}{l}\text { Isolated } \\
\text { hepatocytes }\end{array}$ & & & $\begin{array}{l}\text { Sections of } \\
\text { liver }\end{array}$ & $\begin{array}{l}\text { Isolated } \\
\text { hepatocytes }\end{array}$ \\
\hline \multirow{5}{*}{$\begin{array}{l}\text { R } 6103 \\
\text { U } 5192 \\
\text { Y } 1785 \\
\text { X } 1785 \\
\text { pooled } \\
\text { negative } \\
\text { sera }\end{array}$} & - & + & + & + & - & + & + & + \\
\hline & + & + & + & + & + & + & + & + \\
\hline & + & + & + & + & - & + & + & + \\
\hline & - & - & - & - & - & - & - & - \\
\hline & - & - & - & - & - & - & - & - \\
\hline
\end{tabular}




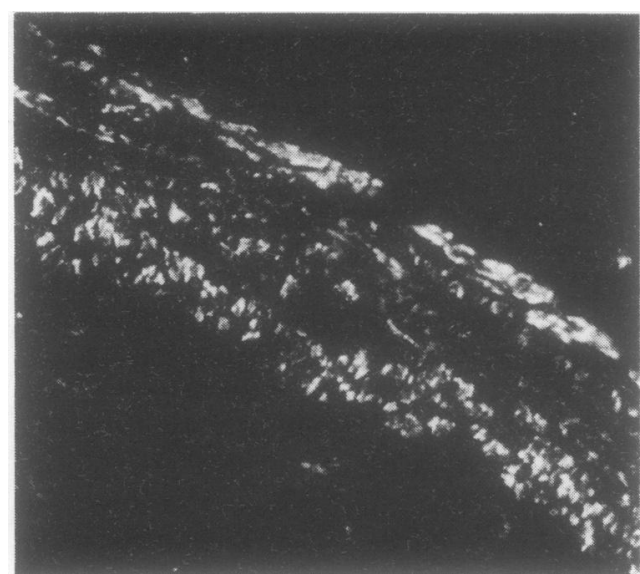

Fig. 2 Staining of smooth muscle by AAA eluate.

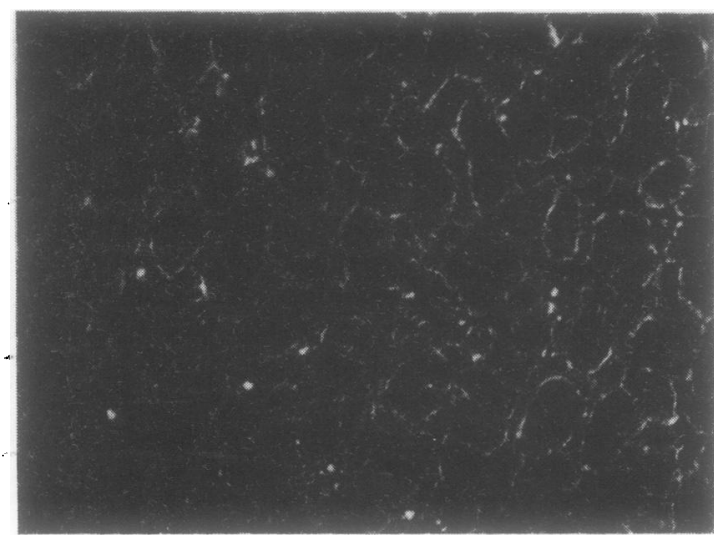

Fig. 3 Staining of sections of liver by AAA eluate.

Antinuclear antibodies (ANA) were found in the eluate of one of three sera containing ANA.

$\mathrm{F}(\mathrm{ab})_{2}$ was produced from all sera giving IgG and IgM hepatocyte membrane staining. The $F(a b)_{2}$ gave the same immunofluorescence membrane

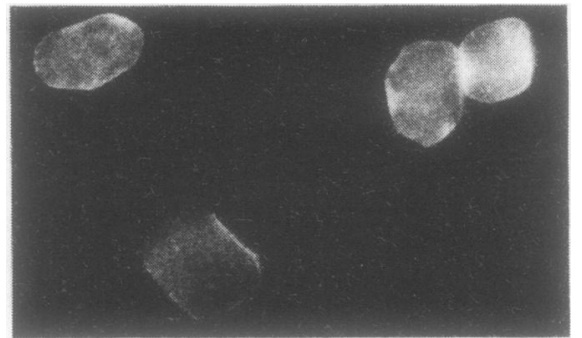

Fig. 4 Staining of isolated hepatocytes by AAA eluate.

staining as the original serum of isolated hepatocytes and the periphery of liver cells in sections of liver. A negative control gave no hepatocyte staining.

\section{Discussion}

Antibodies against actin from human serum has been isolated in the present investigation by affinity chromatography with actin purified by gel filtration. Even though the actin showed only one band at SDS PAGE, minor impurities with other cellular antigens may have been present as the eluate from one of two sera with SMA and ANA reacted both with smooth muscle and cell nuclei. The presence of AAA in the eluate was verified by immunofluorescence with smooth muscle cells.

The AAA extracted from other antibodies to smooth muscle in human sera by affinity chromatography was tested for reactions against the cell membrane of isolated hepatocytes. Our results showed that the IgM antibody eluted from the actin-Sepharose column reacted with the surface of isolated hepatocytes. The IgM antibody eluates also reacted with the periphery of hepatocytes in liver sections.

The staining pattern of liver sections was identical to that found by Lidman et $a l^{6}$ who used eluted AAA from antibody precipitates with actin and also to that of Trenchev et al ${ }^{9}$ who employed rabbit AAA. However, it differed from the pattern

Table 2 Results of investigations for IgG antibodies to smooth muscle cells and liver

\begin{tabular}{|c|c|c|c|c|c|c|c|c|}
\hline \multirow[t]{3}{*}{ Serum No } & \multicolumn{4}{|c|}{ "Whole" serum } & \multicolumn{4}{|c|}{ Chromatographied serum } \\
\hline & \multirow[t]{2}{*}{$A N A$} & \multirow[t]{2}{*}{$\begin{array}{l}\text { Staining of } \\
\text { smooth muscle }\end{array}$} & \multicolumn{2}{|c|}{$\begin{array}{l}\text { Peripheral staining of } \\
\text { hepatocytes }\end{array}$} & \multirow[t]{2}{*}{$A N A$} & \multirow[t]{2}{*}{$\begin{array}{l}\text { Staining of } \\
\text { smooth muscle }\end{array}$} & \multicolumn{2}{|c|}{$\begin{array}{l}\text { Peripheral staining of } \\
\text { hepatocytes }\end{array}$} \\
\hline & & & $\begin{array}{l}\text { Sections of } \\
\text { liver }\end{array}$ & $\begin{array}{l}\text { Isolated } \\
\text { hepatocytes }\end{array}$ & & & $\begin{array}{l}\text { Sections of } \\
\text { liver }\end{array}$ & $\begin{array}{l}\text { Isolated } \\
\text { hepatocytes }\end{array}$ \\
\hline \multirow{5}{*}{$\begin{array}{l}\text { R } 6103 \\
\text { U } 5192 \\
\text { R } 6100 \\
X \quad 1785 \\
\text { pooled } \\
\text { negative } \\
\text { sera }\end{array}$} & - & + & - & - & - & + & - & - \\
\hline & + & + & - & - & + & + & - & - \\
\hline & - & + & - & + & - & + & - & - \\
\hline & + & - & - & - & - & - & - & - \\
\hline & - & - & - & - & - & - & - & - \\
\hline
\end{tabular}


obtained when using AAA produced by immunisation with actin of animals in which a staining of bile canaliculi-like structures were found. ${ }^{13}$

The difference between IgM and IgG AAA is in accordance with our previous investigation in which we found that the occurrence of peripheral IgM hepatocyte fluorescence was related to IgM SMA, whereas IgG peripheral hepatocyte fluorescence was not. ${ }^{10}$ This difference could possibly be due to different antiactin specificities of IgM and IgG AAA. Other investigators have made no distinction between IgG and IgM AAA. ${ }^{613}$ The possibility cannot be excluded that IgM antibody of the eluate might be directed against non-detectable impurities of the actin preparation used for the affinity chromatography column. The reaction of the IgM antibody against hepatocytes seems to be a true antibody reaction since the $F(a b)_{2}$ fraction also reacted with the hepatocytes.

Antibodies reacting with isolated hepatocytes have been described by Hopf $e t$ al $^{11}$ and others ${ }^{14}$ in sera from patients with hepatitis. These antibodies were considered to be directed against liver-specific membrane antigen (LMA). Our investigation appears to demonstrate that the non-organ specific AAA also react with hepatocyte membrane. This is in accordance with the finding of actin in liver cell membrane. ${ }^{15}$ The failing reaction against liver cells of the AAA eluate of R 6100 investigated for IgG antibodies might be due to antibodies reacting with antigens other than actin of the liver cell membrane-that is, LMA.

This work was supported by the Laegevidenskabeligt Forskningsråd. We thank Professor K-H Meyer zum Büschenfelde, who taught us to isolate hepatocytes and Dr Tage Hjort, Århus, who kindly provided the anti- $\mathrm{CH} 2$.

\section{References}

' Diederichsen $H$. Hetero-antibody against bile canaliculi in patients with chronic, clinically active hepatitis. Acta Med Scand 1969;186:299-302.
${ }^{2}$ Hopf U, Meyer zum Büschenfelde K-H, Arnold W. Detection of a liver-membrane autoantibody in $\mathrm{HBsAg-negative} \mathrm{chronic}$ active hepatitis. $N$ Engl J Med 1976;294:578-82.

${ }^{3}$ Johnson GD, Holborow EJ, Glynn LE. Antibody to smooth muscle in patients with liver disease. Lancet 1965;ii:878-9.

4 Farrow LJ, Holborow EJ, Brighton WD. Reaction of human smooth muscle antibody with liver cells. Nature 1971;232:186-7.

${ }^{5}$ Gabbiani G, Ryan GB, Lamelin J-P, et al. Human smooth muscle autoantibody. Its identification as antiactin antibody and a study of its binding to "nonmuscular" cells. Am J Pathol 1973;72:473-88.

- Lidman K, Biberfeld G, Fagraeus A, et al. Anti-actin specificity of human smooth muscle antibodies in chronic active hepatitis. Clin Exp Immunol 1976;24:266-72.

${ }^{7}$ Andersen P, Small, JV, Sobieszek A. Studies on the specificity of smooth-muscle antibodies. Clin Exp Immunol 1976;26:5766.

- Diederichsen H, Riisom K. Anti-actin antibodies revealed by counterimmunoelectrophoresis. Relation to smooth muscle antibodies and bile canalicular antibodies. J Clin Pathol 1980;33:876-9.

9 Trenchev P, Sneyd P, Holborow EJ. Immunoffuorescent tracing of smooth muscle contractile protein antigens in tissues other than smooth muscle. Clin Exp Immunol 1974;16:125-36.

${ }^{10}$ Diederichsen H, Riisom K, Andersen I. Peripheral immunofluorescence of hepatocytes. Relation to smooth muscle antibodies and bile canaliculi. Acta Pathol Microbiol Scand [A] 1977;85:399-404.

" Hopf U, Meyer zum Büschenfelde K-H, Freudenberg J. Liverspecific antigens of different species. Il Localization of a membrane antigen at cell surface of isolated hepatocytes. Clin Exp Immunol 1974;16:117-24.

${ }^{12}$ Poulsen F, Hjort T. A simple method for the production of $F\left(a b^{\prime}\right)_{2}$ preparations by pepsin digestion of total serum protein. Acta Pathol Microbiol Scand [C] 1980;88:241-5.

${ }^{13}$ Toh BH, Yildiz A, Sotelo J, Osung O, Holborow EJ, Fairfax A. Distribution of actin and myosin in muscle and non-muscle cells. Cell Tissue Res 1979;199:117-26.

14 Tage-Jensen U, Arnold W, Dietrichson O, et al. Liver-cellmembrane autoantibody specific for inflammatory liver diseases. Br Med J 1977;i:206-8.

is French SW, Davies PL. Ultrastructural localisation of actin-like filaments in rat hepatocytes. Gastroenterology 1975;68:76574.

Requests for reprints to: Dr Hans Diederichsen, Blood Bank, Odense University Hospital, DK 5000 Odense, Denmark. 